\title{
Front Matter: Volume 11040
}

, "Front Matter: Volume 11040," Proc. SPIE 11040, Optical Design Challenge 2019, 1104001 (28 May 2019); doi: 10.1117/12.2531623

SDIE Event: SPIE Optical Design Challenge, 2019, San Francisco, California, SPIE. United States 


\title{
PROCEEDINGS OF SPIE
}

\section{Optical Design Challenge 2019}

\author{
Bernard C. Kress \\ Christophe Peroz \\ Editors
}

3 February 2019

San Francisco, California, United States

Sponsored by

Microsoft HoloLens

Google LLC (United States)

Amazon.com, Inc. (United States)

Optimax (United Kingdom)

Huawei Technologies Co. Ltd. (China)

Applied Materials, Inc. (United States)

Synopsys (United States)

Zemax LLC (United States)

ZEISS (Germany)

LightTrans International (Germany)

Published by

SPIE 
The papers in this volume were part of the technical conference cited on the cover and title page. Papers were selected and subject to review by the editors and conference program committee. Some conference presentations may not be available for publication. Additional papers and presentation recordings may be available online in the SPIE Digital Library at SPIEDigitalLibrary.org.

The papers reflect the work and thoughts of the authors and are published herein as submitted. The publisher is not responsible for the validity of the information or for any outcomes resulting from reliance thereon.

Please use the following format to cite material from these proceedings:

Author(s), "Title of Paper," in Optical Design Challenge 2019, edited by Bernard C. Kress, Christophe Peroz, Proceedings of SPIE Vol. 11040 (SPIE, Bellingham, WA, 2019) Seven-digit Article CID Number.

ISSN: 0277-786X

ISSN: 1996-756X (electronic)

ISBN: 9781510627468

ISBN: 9781510627475 (electronic)

Published by

SPIE

P.O. Box 10, Bellingham, Washington 98227-0010 USA

Telephone +1 3606763290 (Pacific Time) · Fax +1 3606471445

SPIE.org

Copyright (C) 2019, Society of Photo-Optical Instrumentation Engineers.

Copying of material in this book for internal or personal use, or for the internal or personal use of specific clients, beyond the fair use provisions granted by the U.S. Copyright Law is authorized by SPIE subject to payment of copying fees. The Transactional Reporting Service base fee for this volume is $\$ 21.00$ per article (or portion thereof), which should be paid directly to the Copyright Clearance Center (CCC), 222 Rosewood Drive, Danvers, MA 01923. Payment may also be made electronically through CCC Online at copyright.com. Other copying for republication, resale, advertising or promotion, or any form of systematic or multiple reproduction of any material in this book is prohibited except with permission in writing from the publisher. The CCC fee code is 0277$786 \mathrm{X} / 19 / \$ 21.00$.

Publication of record for individual papers is online in the SPIE Digital Library.

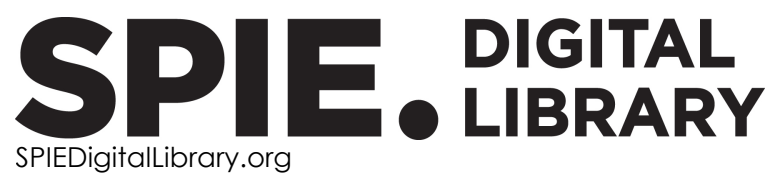

Paper Numbering: Proceedings of SPIE follow an e-First publication model. A unique citation identifier (CID) number is assigned to each article at the time of publication. Utilization of CIDs allows articles to be fully citable as soon as they are published online, and connects the same identifier to all online and print versions of the publication. SPIE uses a seven-digit CID article numbering system structured as follows:

- The first five digits correspond to the SPIE volume number.

- The last two digits indicate publication order within the volume using a Base 36 numbering system employing both numerals and letters. These two-number sets start with 00, 01, 02, 03, 04, 05, 06, 07, 08, 09, OA, OB ... 0Z, followed by 10-1Z, 20-2Z, etc. The CID Number appears on each page of the manuscript. 


\title{
Contents
}

\author{
$\checkmark \quad$ Authors \\ vii Conference Committee
}

\section{OPTICAL DESIGN CHALLENGE}

1104002 Metasurface-based compact light engine for AR headsets [1 1040-1]

1104003 Co-axial depth map sensor with an extended depth range [1 1040-2]

1104004 Design of $\mathrm{Si}_{3} \mathrm{~N}_{4}$ waveguides and components to form an integrated optical network for retinal projection in thin augmented reality glasses [1 1040-3]

1104005 A retinal-projection-based near-eye display with contact lens for mixed reality [11040-4]

1104006 Design and implementation of the Zerotrope: a novel dynamic holographic display [1 1040-5]

1104008 Digitally switchable multi-focal element for wearable displays [11040-7]

1104009 Virtual reality headset using a gaze-synchronized display system (Optical Design Challenge 2019 3rd Place) [1 1040-8]

11040 OB Scanning depth sensor for see-through AR glasses [1 1040-10]

11040 OC Novel design of a quasi-super multi-view head-mounted display [11040-11]

11040 OD 15 focal planes head-mounted display using LED array backlight (Optical Design Challenge 2019 2nd Place) [11040-12]

11040 OE Near-eye light field display with polarization multiplexing (Optical Design Challenge 2019 1st Place) [11040-13] 
Proc. of SPIE Vol. 11040 1104001-4 Downloaded From: https://www.spiedigitallibrary.org/conference-proceedings-of-spie on 26 Apr 2023
Terms of Use: https://www.spiedigitallibrary.org/terms-of-use 


\section{Authors}

Numbers in the index correspond to the last two digits of the seven-digit citation identifier (CID) article numbering system used in Proceedings of SPIE. The first five digits reflect the volume number. Base 36 numbering is employed for the last two digits and indicates the order of articles within the volume. Numbers start with 00, 01, 02, 03, 04, 05, 06, 07, 08, 09, OA, OB...0Z, followed by 10-12, 20-2Z, etc.

Arbabi, Ehsan, 02

Bablumyan, Arkady, 07

Bigler, Colton M., 07

Blanche, Pierre-Alexandre, 07

Chen, Chao Ping, 05

Cho, Jaebum, OD

Choi, Suyeon, OD

Draper, Craig, 07

Faraon, Andrei, 02

Fowler, Daivid, 04

Gentet, Philippe, 06

Gentet, Yves, 06

Herkommer, Alois, 09

Hua, Hong, 03, 08

Jo, Youngjin, OD

Joung, Jinbeom, 06

Kamali, Seyedeh Mahsa, 02

Lee, Byoungho, OD

Lee, Seung-Hyun, 06

Lee, Seungjae, OD

Lee, Yun-Han, OE

Lu, Yifan, 05

Maitlo, Nizamuddin, 05

Mann, Micah S., 07

Markos, Alyson, OB

Martinez, Christophe, 04

Meynard, Basile, 04

Mi, Lantian, 05

Molva, Engin, 04

Navare, Jayesh, OB

Ren, Xingyu, 05

Shahinian, Hossein, OB

Takaki, Yasuhiro, OC

Tan, Guanjun, OE

Tang, Ruixue, 05

Thiele, Simon, 09

Toulouse, Andrea, 09

Ueno, Takaaki, 0C

Wang, Xuan, 08

Wu, Shin-Tson, OE

Xiong, Jianghao, OE

Xu, Mohan, 03

Yoo, Dongheon, OD

Zaytsev, Dmytro, OB

Zhan, Tao, OE

Zhang, Wenbo, 05

Zhu, Ming, 05 
Proc. of SPIE Vol. 11040 1104001-6 Downloaded From: https://www.spiedigitallibrary.org/conference-proceedings-of-spie on 26 Apr 2023
Terms of Use: https://www.spiedigitallibrary.org/terms-of-use 


\title{
Conference Committee
}

\author{
Conference Chair \\ Bernard C. Kress, Microsoft Corporation (United States) \\ Conference Co-chair \\ Christophe Peroz, Magic Leap, Inc. (United States) \\ Conference Program Committee \\ Yi Qin, Google (United States) \\ Weichuan Gao, Oculus VR, LLC (United States) \\ Andreas G. Georgiou, Microsoft Research Cambridge \\ (United Kingdom) \\ Igor Landau \\ Wayne McMillan, Applied Materials, Inc. (United States) \\ Rick Plympton, Optimax Systems, Inc. (United States) \\ Zhujun Shi, Harvard University (United States) \\ Tish Schute, Huawei Technologies Co., Ltd. (United States) \\ Blair L. Unger, Rochester Precision Optics, LLC (United States) \\ Alissa Wilczynski, Zemax, LLC (United States) \\ Frank Wyrowski, LightTrans International UG (Germany) \\ Session Chair \\ Oral Optical Design Challenge \\ Christophe Peroz, Magic Leap, Inc. (United States)
}


Proc. of SPIE Vol. 11040 1104001-8 Downloaded From: https://www.spiedigitallibrary.org/conference-proceedings-of-spie on 26 Apr 2023
Terms of Use: https://www.spiedigitallibrary.org/terms-of-use 